of the fact that studies of terrorism have consistently found that a greater number of lone-actor incidents in Europe and the USA are perpetrated by right-wing extremists or white supremacists ${ }^{13,14}$ and that it is lone actors embracing far-right ideologies that pose a greater threat in Europe than Islamist ones, causing $48 \%$ of terrorism-related fatalities. ${ }^{15}$ It is unclear to us whether opponents of the Prevent strategy in healthcare would have similar qualms about using Prevent mechanisms with, for instance, a future potential Breivik. We can all deplore, with Summerfield, ${ }^{1}$ the way that poor - and possibly illegal British and US foreign policy decisions in Afghanistan and Iraq have had unintended consequences; but we cannot put the clock back. We may not like the way societal changes impinge on our professional duties, but this does not mean we are entitled to turn our back on them.

Jonathan Hurlow, consultant forensic psychiatrist, Birmingham and Solihull Mental Health NHS Foundation Trust, Birmingham, UK, email: jonathon.hurlow@nhs.net, Simon Wilson, consultant and honorary senior lecturer in forensic psychiatry, Barnet, Enfield and Haringey Mental Health NHS Trust and UCL Department of Security and Crime Science, London, UK and David V. James MA, MBBS, FRCPsych, consultant forensic psychiatrist, Theseus LLP, London, UK.

1 Summerfield D. Mandating doctors to attend counter-terrorism workshops is medically unethical. BJPsych Bull 2016; 40: 87-88.

2 Bhui K. Flash, the emperor and policies without evidence: counterterrorism measures destined for failure and societally divisive. BJPsych Bull 2016; 40: 82-84.

$3 \mathrm{BBC}$ News UK. Extremism discussion event held in Bradford by committee. 2016; 28 Jan (http://www.bbc.co.uk/news/uk-england-leeds35430645) (accessed 8 March 2016).

4 Gani A, Slawson N. Lancashire police criticise BBC over 'terrorist house' story. Guardian 2016; 21 Jan (http://gu.com/p/4g2ag/sbl) (accessed 8 March 2016).

5 Anderson D. Supplementary written evidence submitted by David Anderson Q.C. (Independent Reviewer of Terrorism Legislation) to Home Affairs Committee Countering Extremism Inquiry. 2016; 29 Jan (http://data.parliament.uk/writtenevidence/committeeevidence.svc/ evidencedocument/home-affairs-committee/countering-extremism/ written/27920.pdf) (accessed 8 March 2016).

6 HM Government. Revised Prevent Duty Guidance for England and Wales. HM Government, 2016 (https://www.gov.uk/government/ uploads/system/uploads/attachment_data/file/445977/ 3799 Revised Prevent_Duty Guidance_England_Wales_V2Interactive.pdf) (accessed 8 March 2016).

7 General Medical Council. Confidentiality. GMC, 2009 (http://www. gmc-uk.org/guidance/ethical_guidance/confidentiality.asp).

8 Borum R. Informing lone-offender investigations. Criminol Public Policy 2013; 12: 103-112.

9 Capellan JA. Lone Wolf Terrorist or Deranged Shooter? A Study of Ideological Active Shooter Events in the United States, 1970-2014. Stud Conflict Terrorism 2015; 38: 395-413.

10 Gruenewald J, Chermak S, Freilich JD. Distinguishing "Loner" Attacks from Other Domestic Extremist Violence: A Comparison of Far-Right Homicide Incident and Offender Characteristics. Criminol Public Policy 2013; 12: 65-91.

11 McCauley C, Moskalenko S, Van Son B. Characteristics of Lone-Wol Violent Offenders: a Comparison of Assassins and School Attackers. Perspectives on Terrorism 2013; 7: 4-24.

12 Corner E, Gill P. A False Dichotomy? Mental Illness and Lone-Actor Terrorism. Law Hum Behav 2015. 39: 23-34.

13 Spaaij R. Understanding Lone Wolf Terrorism: Global Patterns, Motivations and Prevention. Springer, 2012.

14 Gill P. Lone-Actor Terrorists: A Behavioural Analysis. Routledge, 2015
15 Ellis C, Pantucci R, van Zuijdewijn J, Bakker E, Gomis B, Palombi S, et al. Lone Actor Terrorism: Analysis Paper. Countering Lone-Actor Terrorism Series No. 4. Royal United Services Institute, 2016.

doi: 10.1192/pb.40.3.162

Author's reply: I cannot accept that the Prevent programme is of a piece with everyday psychiatric practice concerning safeguarding and confidentiality. Prevent is about spying and intelligence-gathering and this cannot be ducked.

Hurlow et al are wrong: historically there has been very little relationship between diagnosable mental illness and terroristic acts, which are almost always committed on political grounds. Indeed, most of the terroristic violence in the world is committed by states, not by private individuals. And although it is true that violent radicalised individuals may be from, say, the neo-Nazi right, no one imagines that Prevent was intended to capture anyone other than Muslims. Prevent is part of a wider effort, deeply self-serving, to objectify Muslim culture and religion as carrying explanations for terrorism, so obscuring what damage Western powers have wrought in the Middle East. ${ }^{1}$

1 Kundnani A. The Muslims are Coming!: Islamophobia, Extremism, and the Domestic War on Terror. Verso, 2014.

Derek Summerfield consultant psychiatrist, South London and Maudsley NHS Foundation Trust, London, and honorary senior lecturer, Institute of Psychiatry, Psychology and Neuroscience, King's College London, UK, email: derek.summerfield@slam.nhs.uk

doi: $10.1192 / p b .40 .3 .163$

\section{Secure services for patients should be needs based and locally available}

Dye et al's ${ }^{1}$ timely editorial on 'locked rehabilitation' highlights the need for a closer working relationship between local and specialist commissioners in order to achieve appropriate, least-restrictive local care provision. It also raises the question whether the emergence of locked rehabilitation units is caused by a reduction in open hospital or community-based rehabilitation facilities, combined with a difficulty in accessing low secure units.

In our experience, the pathway into locked rehabilitation is usually via acute in-patient facilities where treatment focus is on stabilisation of mental state and early discharge. In the absence of appropriate open or community-based rehabilitation facilities available locally within the National Health Service (NHS), patients requiring longer periods of rehabilitation are referred for locked rehabilitation in the private sector, usually out of area. A significant minority of these patients have a history of violence, including serious physical assault and fire-setting, but have neither been charged nor convicted.

Regardless of current or future risks, 'gatekeeping assessment' to low secure care on behalf of NHS England relies on the non-clinical requirement that the person has either serious offence charges pending or has been convicted of an offence. This becomes a barrier to accessing appropriate local secure care because in some areas police are reluctant to charge patients with long-term psychotic problems, as it may be clear that eventually they will receive a psychiatric

\title{
Bulletin
}


disposal. Clearly defined criteria for gatekeeping assessment are not readily available for referrers, although the Joint Commissioning Panel for Mental Health refers to a guidance to improve assessment consistency. ${ }^{2}$ If the criteria set out by the Department of Health are taken as a reference, ${ }^{3}$ a substantial majority of patients undergoing locked rehabilitation would satisfy them.

There is a need for clarity and transparency to ensure accessible, equitable and local care to this vulnerable group of patients. Local and specialist commissioners need to redefine secure rehabilitation care pathways with input from both general adult and forensic mental health professionals to make low secure care more needs based than based on legal charge. To improve patient care, a review of allocation of financial resources across the low secure/locked rehabilitation healthcare system involving both general adult and forensic mental health professionals is urgently required.

Ilyas Mirza, consultant psychiatrist and Mukesh Kripalani, locum consultant psychiatrist, Barnet Enfield and Haringey Mental Health NHS Trust, London, UK, email: ilyas.mirza@beh-mht.nhs.uk

1 Dye S, Smyth L, Pereira S. 'Locked rehabilitation': a need for clarification. BJPsych Bull, 2016, 40: 1-4.

2 Joint Commissioning Panel for Mental Health. Guidance for Commissioners of Forensic Mental Health Services. JCPMH, 2013. (http://jcpmh.info/wp-content/uploads/jcpmh-forensic-guide.pdf).

3 Department of Health Low Secure Services. Good Practice Commissioning Guide, Consultation Draft. Department of Health, 2012. (http:// apps.bps.org.uk/_publicationfiles/consultation-responses/ Low\%20Se...).

doi: $10.1192 / \mathrm{pb} .40 .3 .163 \mathrm{a}$ 